\title{
Determination of the Hazard Class of Ash After Coal Combustion by the Method of Biotesting
}

\section{SVYATOSLAV ANDREEVICH BUSHUMOV*, TATYANA GERMANOVNA KOROTKOVA, SVETLANA JUREVNA KSANDOPULO, NATALIYA VLADIMIROVNA SOLONNIKOVA and VLADIMIR IVANOVICH DEMIN}

\author{
Kuban State Technological University, 350002 Russian Federation, Krasnodar, \\ Moskovskaya Street, 2, Russia. \\ Corresponding author E-mail: bushumovs@mail.ru \\ http://dx.doi.org/10.13005/ojc/340130
}

(Received: August 17, 2017; Accepted: November 25, 2017)

\begin{abstract}
Ash and slag wastes after coal combustion at power plants are usually considered as environmentally non-hazardous. The term "toxic" is not applied to ash and slag. This article discusses the results by researchers of several countries concerning the aspect of determination of hazard class of ash and slag wastes after coal combustion at power plants. Toxicity of ash and slag mixture has been determined experimentally using test organisms, contrary result has been obtained. Biotesting has been performed according to testing procedures (the Russian Federation) specified by the Federal Register, FR 1.39.2007.03222 and FR 1.39.2007.03223. While analyzing toxicity of ash and slag mixture after combustion of culm of Donetsk deposit (Russia), acute toxic impact water extract from waste on test organisms, Daphnia magna Straus and weeds Scenedesmus guadricauda, was revealed. Non-hazardous dilution factor water extract from waste has been detected, causing lethality of not more than $10 \%$ of daphnia in $96 \mathrm{~h}$ and deviation of quantity of weeds not higher than by $20 \%$ in $72 \mathrm{~h}$ in comparison with reference. Ash and slag wastes are classified as hazard class III-IV for environment which agrees with the results by other researchers.
\end{abstract}

Keywords: Fly ash, Slag ash, Biotesting, Thermal power plant.

\section{INTRODUCTION}

Hazard class of ash and slag wastes is important in terms of environmental protection and health of inhabitants residing in vicinity of power plants. Ash dumps exert negative impact on environment due to dusting and on water sources due to effluents of toxic elements into surface and ground water. Ground waters are used as sources of water consumption in urban and rural areas. Determination of hazard class is required for assessment of environmental damage upon

This is an Open Access article licensed under a Creative Commons Attribution-NonCommercial-ShareAlike 4.0 International License (https://creativecommons.org/licenses/by-nc-sa/4.0/ ), which permits unrestricted NonCommercial use, distribution and reproduction in any medium, provided the original work is properly cited. 
handling of wastes as well as for determination of waste disposal limits and costs of its storage. Classifying wastes as hazard class in Russia is based on calculations (quantitative chemical analysis) and experiments methods. Experimental method is based on biotesting of water extracts on test organisms which, according to Braginsky, are "sensors" of data on toxicity of medium. Biotesting in many countries is based on various hydrobionts: weeds, microorganisms, invertebrates, fishes. In Russia biotesting is legally permitted with crustaceans (daphnia or ceriodaphnia), weeds (Scenedesmus or Chlorella), and fishes (guppy or Danio). Biotesting methods consider for the extent of complex impact of all pollutants of tested sample, that is, provide integral assessment. Hazard class is determined on the basis of dilution factor of water extract at which no harmful impact on biological samples is detected.

This work discusses biotesting of ash and slag wastes of Novocherkassk state district power plant (Rostov region, Russia). The wastes are generated after combustion of Donetsk culm.
The main fuel of power plant is coal, its combustion results in generation of ash and slag wastes. These wastes are stored in specialized ash dumps.

In Russia five hazard classes of wastes are established for environment (Decree of the Ministry of Natural Resources and Environment of the Russian Federation, No. 536 dated December 04, 2014, "On approval of criteria of hazard classes I-V in terms of negative environment impact"), four hazard classes of wastes - for human health (SR 2.1.7.1386-03 "Sanitary rules of determination of hazard of toxic industrial and domestic wastes", approved by the Ministry of health of the Russian Federation on June 16, 2003). The essence of both procedures is to calculate summary hazard index of waste $\mathrm{K}$ on the basis of a set of hygienic, toxicological and other properties of components (Table. 1). Classifying of wastes as the fifth hazard class is based on impact water extract from waste without its dilution.

Table. 1: Hazard classes of wastes

\begin{tabular}{|c|c|c|}
\hline Hazard class & $«$ Criteria....» & SR 2.1.7.1386-03 \\
\hline Class $1-$ extremely hazardous & $10^{6} \geq \mathrm{K} \geq 10^{4}$ & $K \geq 5 \cdot 10^{4}$ \\
\hline Class 2 - highly hazardous & $10^{4} \geq \mathrm{K} \geq 10^{3}$ & $5 \cdot 10^{4} \geq \mathrm{Ke} " 10^{3}$ \\
\hline Class 3 - moderately hazardous & $10^{3} \geq \mathrm{K} \geq 10^{2}$ & $10^{3} \geq \mathrm{Ke} \geq 10^{2}$ \\
\hline Class 4 - low hazardous & $10^{2} \geq \mathrm{K} \geq 10$ & $10^{2} \geq \mathrm{K}$ \\
\hline Class 5 - virtually non-hazardous & $10 \geq K$ & - \\
\hline
\end{tabular}

According to the researchers ${ }^{1-3}$, ash and slag wastes of thermal power plants in the world are considered as non-hazardous (the term "toxic" is not applied to ash and slag) and nowhere in the world the content of microelements in ash of thermal power plants exceeds the approved maximum concentrations of microelements above which wastes are considered as hazardous. According to the USA regulations ash and slag after coal combustion with acid ash composition are considered as non-hazardous. This opinion ${ }^{1-3}$ is confirmed by biotesting of water extracts from ash and slag after coal combustion with acid ash of numerous Russian deposits, that is, actually nonhazardous wastes for environment. Hazard class $\mathrm{V}$ is determined according to the established classification (Decree of the Ministry of Natural Resources and Environment of the Russian Federation, No. 536 dated December 04, 2014). These researchers ${ }^{3}$ discussed unjustified classification of ash and slag wastes as hazard class IV (low hazardous) instead of class V (virtually nonhazardous). Calculations reveal that ash and slag after combustion of numerous considered coals are classified as hazard class $\mathrm{V}$; herewith, it is mentioned that this conclusion is not always confirmed by biotesting. Ash and slag after coal combustion contain potentially hazardous microelements, which can be harmful if their concentration exceeds significantly maximum allowable concentration in soil (MAC(s)). Serbian researchers ${ }^{4}$ also believe that the wastes generated 
at coal combustion facilities are usually characterized by low internal toxicity and are not hazardous for human health and environment.

Our investigations presented in this article do not confirm the conclusions summarized $i^{1-4}$. Let us consider results by researchers of various countries concerning determination of hazard class of ash and slag after coal combustion at thermal power plants and state district power plant.

The work $^{5}$ discusses conventional insulation of ash dump by coating of their surface with natural vegetable soil with subsequent sowing of perennial grasses. It is established that the main bulk of heavy metals is held by plant roots and minor portion migrates into subsurface soil. Elements migrate from soil with gravitational waters, which comparatively rapidly penetrate across soil stratum. Such waters are known as lysimetric.

Results of chemical analysis of toxic elements in ash and slag are compared with normative concentration of monitored substances ${ }^{6}$. It follows that excess concentrations of toxic elements with regard to $\mathrm{MAC}(\mathrm{s})$ in gross form of ash and slag wastes are observed for chromium, plumbum, mercury arsenic. In 70 analyzed slag samples from power plants high content of chromium, plumbum, mercury, tin, and antimony are detected, their concentrations are significantly higher than MAC(s). It is experimentally found that ash and slag wastes upon contact with water are a source of toxic elements (vanadium, molybdenum, arsenic, nickel, zinc, manganese and chromium) in ground waters in the vicinity of ash and slag dumps and natural water sources. Significant migration of active forms of heavy metals (copper, nickel, zinc, plumbum) from ash and slag dumps into soils is observed despite low concentrations of nickel and zinc in gross form.

These researches ${ }^{5,6}$ confirm the fact that heavy metals penetrate into plants via root system and into ground waters with gravitational (infiltration) waters. As a consequence of motion of underground waters, they penetrate into surface water sources (lakes, rivers and so on), which leads to suppression of living organisms and plants. Therefore, accumulation of heavy metals results in continuous impairment of lithosphere and hydrosphere.

As mentioned in the Introduction, standard biotesting systems make it possible to assess reliably at laboratory scale the toxicity level of wastes aiming at environmental standardization of harmful impacts. $\ln ^{7}$ the analytical results are compared according to two procedures used for assessment of ecotoxicity of waste samples and environment. These testing systems are from different taxon groups: entomostracans Daphnia magna and protozoans Paramecium caudatum. It is established that despite the pollution pattern of sample the most sensitive is testing on daphnia, testing with protozoansis characterized by significantly lower sensitivity, while comparing the extracts from ash and slag wastes from various regions of Russia neutralized by two different procedures different responses of test organisms were obtained.

Chemical analysis and biotesting of ash and slag wastes of Ltd "Siberian Barrel" (Russia) with ceriodaphnia and paramecium revealed hazard class IV ${ }^{8}$.

In $^{9}$ samples of fly ash (A, B, C, D, E) were obtained from European coal combusting thermal power plants (Great Britain - À, B, Austria - C, Italy $D, E)$. Elemental analysis was performed by inductively coupled plasma atomic emission spectroscopy (ICP-AES) and X-ray fluorescence (XRF). All samples are characterized with high amount of aluminum (about $100 \mathrm{~g} / \mathrm{kg}$ ) and silicon (about $200 \mathrm{~g} / \mathrm{kg}$ ), iron and calcium, as well as with traces of chromium, copper, manganese, and zinc. Toxicity of ash samples was determined according to EN 14735 (CEN, 2003). Rotifers (Brachionus calyciflorus) and crustaceans (Daphnia magna) were used as tested samples. $7 \mathrm{~g}$ of $35 \mathrm{ml}$ solution of sodium chloride with 2 wt \% (dilution factor 1:5) on the basis of deionized water were extracted in 10 minutes. After extraction the samples were tested on living organisms for 24 hours. The highest lethality (nearly 100\%) of daphnia was observed upon testing of ash $A$, which is stipulated by high content of heavy metals in sample.

The researchers ${ }^{10}$ studied the influence of fly ash of heat and power plants with low calcium content on biota. Portland cement was used as a 
sample with high content of calcium silicate $(70-80 \%)$ aiming at subsequent comparison with ash analyses. Fly ashes from Troitsk, Reftinsky, and Novotroitsk thermal power plants were analyzed. Microorganisms, hydrobionts and higher plants were used as test objects. It is mentioned that fly ash does not have toxic impact on microorganisms, such as microfungus (ascomycetous fungi). Water extract from ash samples has acute toxic impact on hydrobionts, Daphnia Magna (water extract of nearly all samples resulted in $100 \%$ lethality of test objects in $24 \mathrm{~h}$ ). Analysis of these biotesting results of water extracts demonstrated minor toxic impact on higher plants, Avéna satíva (the highest lethality was $19.3 \%$, which does not exceed the specified norm of $20 \%$, but is sufficiently close to it).

Study of ash and slag wastes generated upon combustion of Kansk-Achinsk coals (Russia) ${ }^{11}$ demonstrated that they contain highly and moderately hazard mineral substances and polycyclic aromatic hydrocarbons which are involved into natural cycles due to migration into ground waters, soil and surrounding air. Gross concentrations of chromium, manganese, nickel, cobalt, zinc, arsenic, copper in certain types of ash and slag wastes are by far higher than MAC in soil. In the disposal areas of ash and slag wastes the concentrations of iron, manganese and aluminum in ground waters and of manganese, copper, nickel, cobalt, plumbum and zinc in soil are significantly higher than MAC. The tests performed on warmblooded animals proved that the ash and slag wastes generated upon combustion of KanskAchinsk coals are toxic with thresholds of acute impact of $90 \mathrm{mg} / \mathrm{kg}$ and damages of liver, kidneys and stomach, they exert mutagenic impact on microbe test objects, toxic impact on hydrobionts. Study of phytotoxic impact in tests upon wheat sprouting in artificial soil with addition of ash and slag wastes demonstrated that increase in ash and slag wastes portion in artificial soil suppresses sprouting and development of root system of seedlings, pronounced root growth inhibition is observed. It was determined by calculations that ash and slag wastes in terms of macrocomponent content are classified as hazard class III, and in terms of microcomponent content as hazard class IV. According to toxicometry of ash and slag wastes generated upon combustion of all Kansk-Achinsk coals are classified as hazard class III-IV of industrial wastes.

Therefore, the results of toxicity of ash and slag waste after coal combustion are various. The existence of toxic microelements in these wastes is evident. The test on daphnia, Daphnia Magna, is the most sensitive.

\section{METHODS}

Biotesting of ash and slag mix was performed in accordance with Russian biological test procedures specified in the Federal register: FR 1.39.2007.03222 and FR 1.39.2007.03223. FR 1.39.2007.03222 is based on determination of lethality and variation in fertility of daphnia (Daphnia magna Straus, Cladocera, Crustacea) upon impact of toxic substances existing in the considered aqueous medium in comparison with samples without toxic substances (reference). Criterion of acute toxicity is lethality of at least $50 \%$ daphnia in $96 \mathrm{~h}$ in the considered water provided that in reference case lethality does not exceed $10 \%$. FR 1.39.2007.03223 is based on recording of decrease in fluorescence of chlorophyll and decrease in quantity of protococcus cells: Scenedesmus quadricauda (Turp.) Breb. or Selenastrum capricornutum under laboratory conditions upon impact of toxic substances existing in the considered water extract (test) in comparison with reference sample without toxic substances (reference). Criterion of acute toxicity is suppression of fluorescence level of chlorophyll and decrease in quantity of weed cells by $50 \%$ and more in comparison with reference in $72 \mathrm{~h}$ exposure.

\section{RESULTS}

$\ln ^{12}$ we determined quantitative chemical analysis of ash and slag wastes from Novocherkassk state district power plant: ash mixture from transportation system; ash sampled from cyclone, and ash sampled from bag filters. It was found that the hazard index of ash mixture from transportation system (cumulative value) $\mathrm{K}$ is 96.904. It is close to 100 . Thus, the environmental hazard class can be evaluated as III-IV. The values of $\mathrm{K}_{i}$ for ash from cyclone and ash from bag filters 
are 65.966 and 30.166 , respectively. The environmental hazard class is IV.

It is known that averaged chemical composition of Earth in total is calculated on the basis of data on content of elements in meteorites. Clark number (or clark) of element expresses average content of chemical element in earth crust, hydrosphere, space bodies and so on referring to total weight of this system and serves as reference of decreased or increased concentrations of chemical elements in mineral deposits, rocks, wastes and so on. Upon migration of elements their clarks are quantitative indices of their concentration.
Clark are measured in $\mathrm{mg} / \mathrm{kg}$. Table. 2 summarizes contents of chemical elements by various researchers and determined by $u^{12}$ in ash mixture after combustion of culm (Novocherkassk state district power plant, Russia), the rate of its pollution is assessed. The elements contained in coals and coal ashes in excess of clark are referred to as typomorphic or characteristic. Such elements include mercury, lead, manganese, selenium, antimony, bismuth, calcium. Mercury, plumbum, manganese, antimony and bismuth are heavy metals. Calcium is alkaline earth metal, its existence in soil is estimated positively. Necessity of selenium for living organisms, as the author $i^{13}$ believes, is not doubtful.

Table. 2: Abundances of elements in environment, $\mathrm{mg} / \mathrm{kg}$

\begin{tabular}{|c|c|c|c|c|c|c|}
\hline $\begin{array}{l}\text { Chemical } \\
\text { element }\end{array}$ & Symbol & $\begin{array}{l}\text { In earth crust, } \\
\text { Taylor S.R. } \\
1964^{14}\end{array}$ & $\begin{array}{l}\text { In granite layer } \\
\text { of continental crust } \\
\text { Beus A. A. } 1976^{15}\end{array}$ & $\begin{array}{l}\text { In Earth } \\
\text { crust }^{16}\end{array}$ & $\begin{array}{c}\text { Content in } \\
\text { ash mixture }\end{array}$ & $\begin{array}{c}\text { Contamination } \\
\text { level }\end{array}$ \\
\hline Cadmium & $\mathrm{Cd}$ & 0.2 & 0.16 & 6.1 & $<0.1$ & weak \\
\hline Copper & $\mathrm{Cu}$ & 55 & 22 & 68 & $34.4 \pm 8.6$ & below clark \\
\hline Mercury & $\mathrm{Hg}$ & 0.08 & 0.033 & 0.08 & $<0.1$ & above clark \\
\hline Nickel & $\mathrm{Ni}$ & 75 & 26 & 99 & $<0.5$ & weak \\
\hline Plumbum & $\mathrm{Pb}$ & 12.5 & 16 & 13 & $17 \pm 4$ & above clark \\
\hline Zinc & $\mathrm{Zn}$ & 70 & 51 & 76 & $<1.0$ & weak \\
\hline Cobalt & Co & 25 & 7.3 & 29 & $<0.5$ & weak \\
\hline Iron & $\mathrm{Fe}$ & 56300 & 36000 & 62000 & $16655 \pm 4164$ & below clark \\
\hline Manganese & $\mathrm{Mn}$ & 950 & 700 & 1060 & $1138 \pm 285$ & above clark \\
\hline Arsenic & As & 1.8 & 1.9 & 1.8 & $<0.1$ & below clark \\
\hline Selenium & $\mathrm{Se}$ & 0.05 & 0.14 & 0.05 & $<0.1$ & above clark \\
\hline Antimony & $\mathrm{Sb}$ & 0.20 & 0.20 & 0.20 & $<1.0$ & above clark \\
\hline Bismuth & $\mathrm{Bi}$ & 0.17 & 0.01 & 0.008 & $<1.0$ & strong \\
\hline Calcium & $\mathrm{Ca}$ & 41500 & 25000 & 46000 & $145714 \pm 36429$ & 9 above clark \\
\hline Aluminum & $\mathrm{Al}$ & 82300 & 80000 & 83000 & $62 \pm 16$ & weak \\
\hline
\end{tabular}

In Russia regulations on allowable concentrations of substance in soil are valid ${ }^{17,18}$ (Table 3). Copper content in ash mixture, 34.4 $\pm 8,6$ $\mathrm{mg} / \mathrm{kg}$, exceeds $\mathrm{MAC}(\mathrm{s})$ more than in 10 times. Plumbum content in ash mixture, $17 \pm 4 \mathrm{mg} / \mathrm{kg}$, exceeds MAC(s) in 3 times (active forms).

Crustaceans (Daphnia magna Straus) (Fig. 1) and weeds (Scenedesmus quadricauda) (Fig. 2) were elected as test objects for biotesting of ash mixture sampleds from transportation system; from cyclone; and from bag filters. The biotesting procedure is illustrated in Figure. 3.
In the course of toxic analysis of ash mixture (Tables. 4 and 5) acute toxic impact of water extract from waste on test organisms was detected: Daphnia magna Straus and weeds Scenedesmus quadricauda; non-hazardous dilution factor of water extract was determined causing lethality of not more than $10 \%$ of daphnia in $96 \mathrm{~h}$ and deviation of weed quantity not more than by $20 \%$ in $72 \mathrm{~h}$ regarding reference.

According to the biotesting results the waste is classified as environmental hazard class IV. Similarly, toxic analysis was performed for ash 
sampled from cyclone (water extract $\mathrm{pH}$ 6.82) and ash sampled from bag filters (water extract $\mathrm{pH}$ 6.25) (Table. 6).
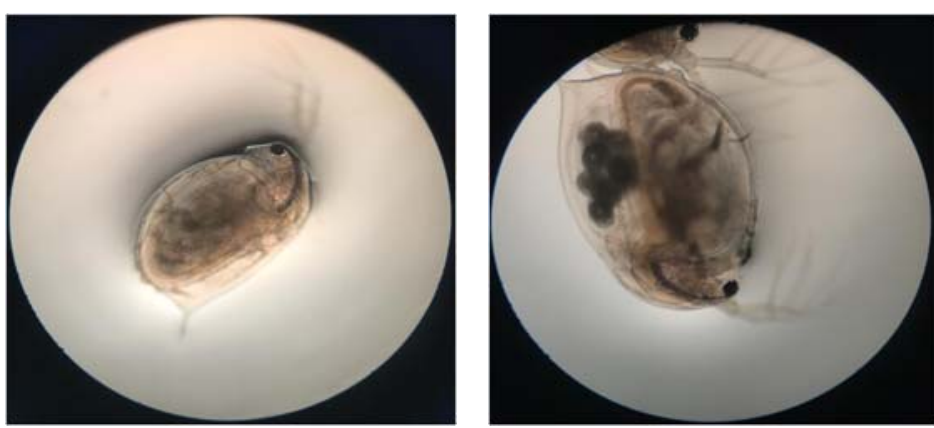

Fig. 1. Daphnia magna Straus. (Photo by S. A. Bushumov)

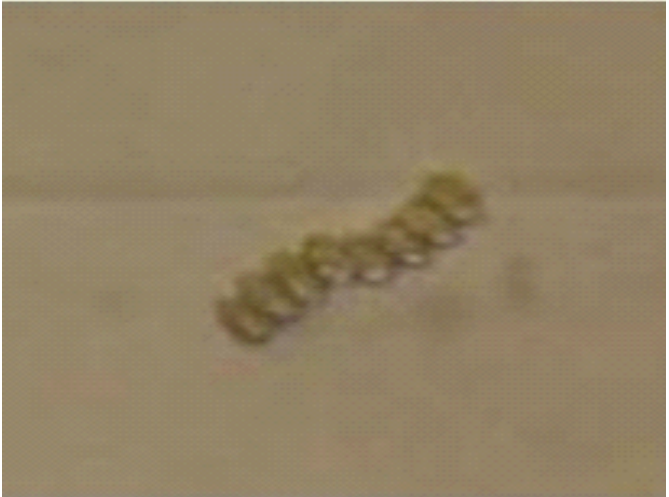

Fig. 2. Scenedesmus quadricauda. (Photo by S. A. Bushumov)

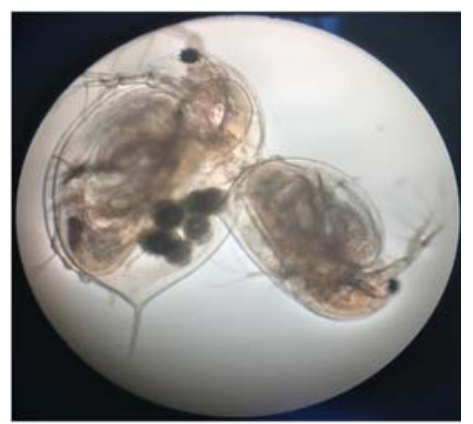

According to the biotesting results the waste is classified as environment hazard class IV.

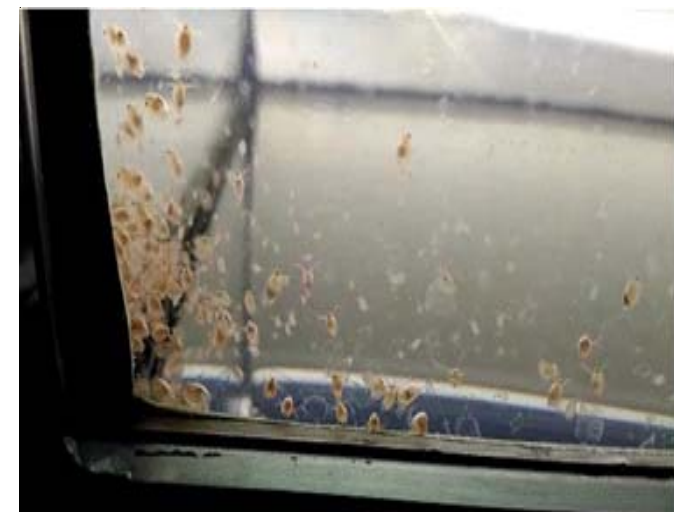

Fig. 3. Biotesting procedure. (Photo by S. A. Bushumov)

Table. 3: Content of elements, $\mathrm{mg} / \mathrm{kg}$

\begin{tabular}{|c|c|c|c|c|}
\hline $\begin{array}{l}\text { Chemical } \\
\text { element }\end{array}$ & Symbol & $\begin{array}{l}\text { Content in ash } \\
\text { mixture, mg/kg }\end{array}$ & $\begin{array}{c}\mathrm{MAC}(\mathrm{s}) \\
\mathrm{mg} / \mathrm{kg}\end{array}$ & $\begin{array}{c}\text { TAC (max), } \\
\mathrm{mg} / \mathrm{kg}\end{array}$ \\
\hline Cadmium & $\mathrm{Cd}$ & $<0.1$ & Carcinogenicity proved for human & 2.0 \\
\hline Copper & $\mathrm{Cu}$ & $34.4 \pm 8.6$ & 3 a.f. & 132 \\
\hline Mercury & $\mathrm{Hg}$ & $<0.1$ & 2.1 g. c. & - \\
\hline Nickel & $\mathrm{Ni}$ & $<0.5$ & 4 a.f. & 80 \\
\hline Plumbum & $\mathrm{Pb}$ & $17 \pm 4$ & 32 g. c.; 6 a. f. & 130 \\
\hline Zinc & $\mathrm{Zn}$ & $<1.0$ & 23 a.f. & 220 \\
\hline Cobalt & Co & $<0.5$ & 5 a.f. & - \\
\hline Iron & $\mathrm{Fe}$ & $16655 \pm 4164$ & - & - \\
\hline Manganese & $\mathrm{Mn}$ & $1138 \pm 285$ & 1500 g. c. & - \\
\hline Arsenic & As & $<0.1$ & 2 g. c. & 10 \\
\hline Selenium & Se & $<0.1$ & $10[13]$ & - \\
\hline Antimony & $\mathrm{Sb}$ & $<1.0$ & 4.5 g. c.. & - \\
\hline Bismuth & $\mathrm{Bi}$ & $<1.0$ & - & - \\
\hline Calcium & $\mathrm{Ca}$ & $145714 \pm 36429$ & - & - \\
\hline Aluminum & $\mathrm{Al}$ & $62 \pm 16$ & - & - \\
\hline
\end{tabular}

Note: $\mathrm{MAC}(\mathrm{s})(\mathrm{mg} / \mathrm{kg})$ - Maximum allowable concentration of chemical element in soil ${ }^{17}$; TAC (mg/kg) - Tentative allowable concentration of chemical element in soil ${ }^{18}$; a.f. - active form; g.c. - gross content; blank - not determined 
Table. 4: Results of toxicology tests

Description of waste

Biotesting medium

Water extract $\mathrm{pH}$
Ash and slag mixture after coal combustion, low hazardous Water extract from waste 7.43

\begin{tabular}{lccc}
\hline Test sample & Duration, h & Non-hazardous dilution factor & $\begin{array}{c}\text { Assessment of tested } \\
\text { sample }\end{array}$ \\
\hline $\begin{array}{l}\text { Daphnia magna Straus } \\
\text { FR 1.39.2007.03222 }\end{array}$ & 96 & w/o d. $<$ NHRD $<100$ & Acute toxic impact \\
$\begin{array}{l}\text { Scenedesmus quadricauda } \\
\text { FR 1.39.2007.03223 }\end{array}$ & 72 & w/o d. $<$ NHRD $<100$ & \\
\hline
\end{tabular}

Note: w/o d - without dilution

Table. 5: Toxicology test of ash and slag mixture from transportation system

\begin{tabular}{|c|c|c|c|c|c|c|c|c|c|c|c|c|c|c|c|c|}
\hline 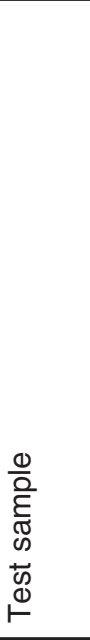 & 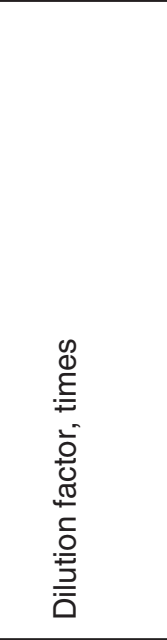 & 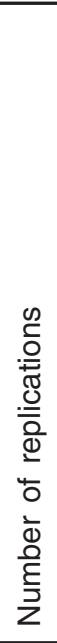 & 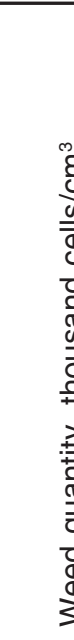 & 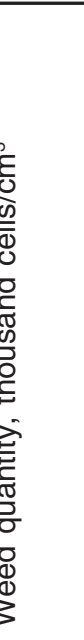 & 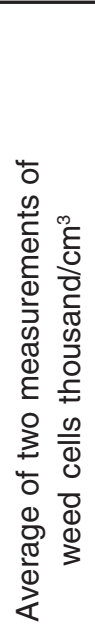 & 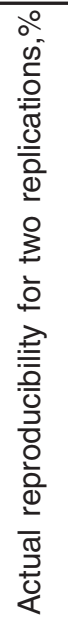 & 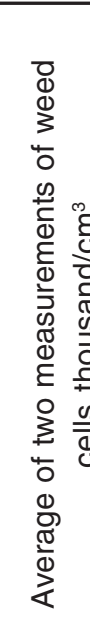 & 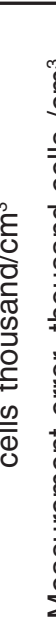 & 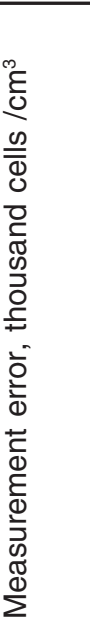 & & 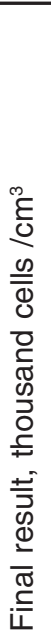 & & 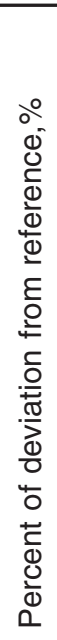 & 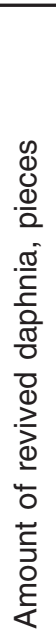 & 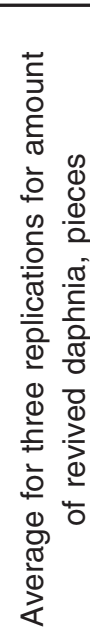 & 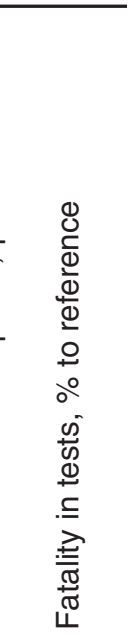 \\
\hline \multirow{12}{*}{ 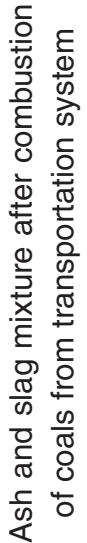 } & \multirow[t]{3}{*}{ Reference } & 1 & 360 & 370 & 370 & \multirow[t]{3}{*}{4} & \multirow[t]{3}{*}{378} & \multirow[t]{3}{*}{ \pm} & \multirow[t]{3}{*}{121} & \multirow[t]{3}{*}{378} & \multirow[t]{3}{*}{ \pm} & \multirow[t]{3}{*}{121} & \multirow[t]{3}{*}{-} & 10 & \multirow[t]{3}{*}{10} & \multirow[t]{3}{*}{-} \\
\hline & & 2 & 390 & 380 & 385 & & & & & & & & & 10 & & \\
\hline & & 3 & & & & & & & & & & & & 10 & & \\
\hline & \multirow[t]{3}{*}{ w/o d. } & 1 & 280 & 280 & 280 & \multirow[t]{3}{*}{8.5} & \multirow[t]{3}{*}{293} & \multirow[t]{3}{*}{ \pm} & \multirow[t]{3}{*}{94} & \multirow[t]{3}{*}{293} & \multirow[t]{3}{*}{ \pm} & \multirow[t]{3}{*}{93.6} & \multirow[t]{3}{*}{23} & 7 & \multirow[t]{3}{*}{7.67} & \multirow[t]{3}{*}{23.3333} \\
\hline & & 2 & 310 & 300 & 305 & & & & & & & & & 9 & & \\
\hline & & 3 & & & & & & & & & & & & 7 & & \\
\hline & \multirow[t]{3}{*}{50} & 1 & 320 & 310 & 315 & \multirow[t]{3}{*}{3.1} & \multirow[t]{3}{*}{320} & \multirow[t]{3}{*}{ \pm} & \multirow[t]{3}{*}{102} & \multirow[t]{3}{*}{320} & \multirow[t]{3}{*}{ \pm} & \multirow[t]{3}{*}{102} & \multirow[t]{3}{*}{15} & 10 & \multirow[t]{3}{*}{9.33} & \multirow[t]{3}{*}{6.6667} \\
\hline & & 2 & 330 & 320 & 325 & & & & & & & & & 9 & & \\
\hline & & 3 & & & & & & & & & & & & 9 & & \\
\hline & 100 & 1 & 350 & 340 & 345 & 5.6 & 355 & \pm & 114 & 355 & \pm & 114 & 6 & 10 & 10.00 & 0 \\
\hline & & 2 & 370 & 360 & 365 & & & & & & & & & 10 & & \\
\hline & & 3 & & & & & & & & & & & & 10 & & \\
\hline
\end{tabular}


Table. 6: Toxicology test of ash and slag mixture from cyclones and bag filters

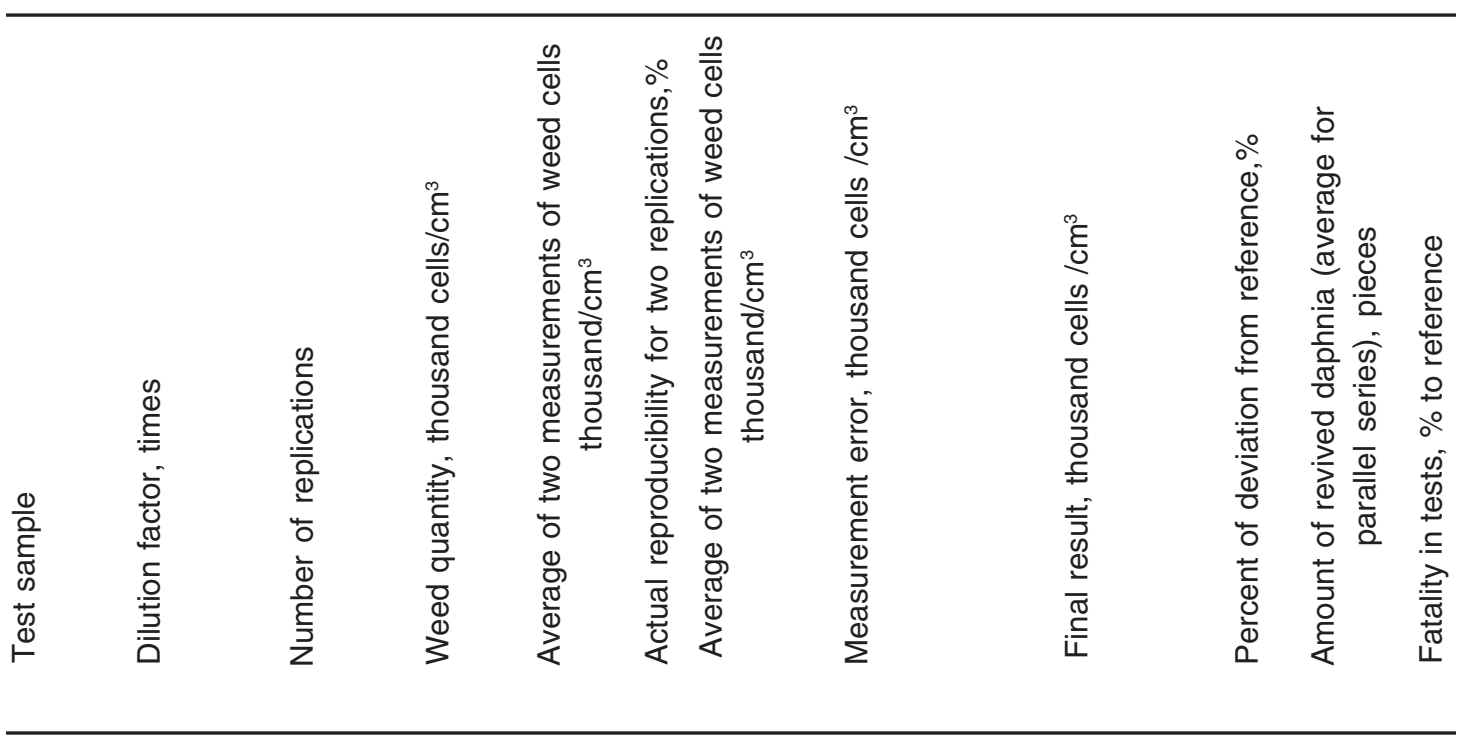

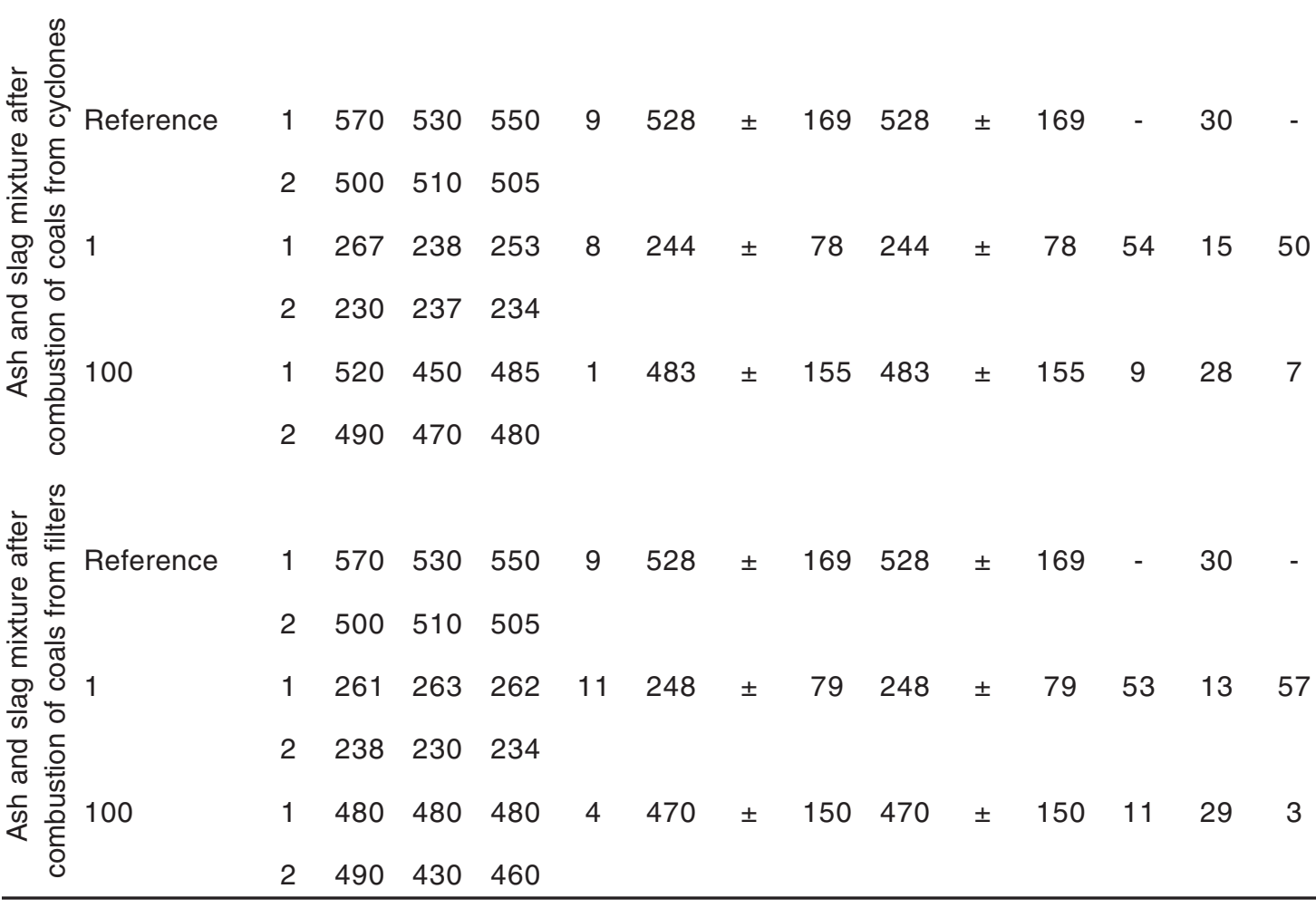

\section{DISCUSSION}

X-ray structure analysis evidences that the ash mainly contains crystalline quartz, anhydride, compounds of calcium oxide with iron oxides and aluminum (dicalcium silicate, tetracalcium alumoferrite, calcium aluminates, calcium ferrites); then, glass phase, hematite and impurities, as well as $\mathrm{CaO}$ and $\mathrm{MgO}$ in free state.

The performed studies of physical properties of dry ash demonstrated that the ash is mainly comprised of regular globular particles of brownish color without impurities. The sizes of 
spherical particles range from $0.5 \mu \mathrm{m}$ to $20 \mu \mathrm{m}$, diameter of single particles reaches $30 \ldots 40 \mu \mathrm{m}$. The ash is characterized by high density in comparison with acid ashes after combustion of bituminous coals. Thus, the ash bulk density is in the range of $1200 \ldots 1500 \mathrm{~kg} / \mathrm{m}^{3}$, the real density is in the range of $2900 \ldots 2950 \mathrm{~kg} / \mathrm{m}^{3}$, specific surface area is $3021 \mathrm{~cm}^{2} / \mathrm{g}$. The ash after combustion of brown coal at power plane contains high amounts of calcium, the content of calcium oxide is $25 \ldots 40 \%$, and the content of silica and alumina in this ash is significantly lower, $30 \%$ and $15 \%$, respectively. The content of unburned particles and alkaline components is low. All these factors make it possible to use the ash as raw stock for production of mineral fiber.

Our studies of ash particle size distribution ${ }^{19}$ demonstrated that the ash is finely dispersed, its specific surface area is high, it is a final product of short-term high temperature annealing. Its mineral portion contains annealed, vitrified and partially crystallized particles characterized by various degree of chemical and hydraulic activity, it contains minor amounts of organic particles exposed to burning. The ash can be efficiently used as additive for production of concretes, mortars, and dry construction mixes. This would allow to recover wastes of thermal power production and to decrease prime costs of construction materials.

\section{CONCLUSIONS}

Toxicology tests of water extract after coal combustions demonstrated that the considered sample exerts acute toxic influence. Ash and slag wastes are classified as environmental hazard classes III-IV. Long term storage of ash and slag in dumps can result in variation of hazard class and toxicity. Hygienic assessment is required including laboratory tests.

\section{REFERENCES}

1. Dik E.P.; Soboleva A.N. Otsenka stepeni opasnosti zoloshlakovykh othodov TES dlya okruzhaiushchei sredy i zdorov'ia cheloveka [Assessment of hazard of ash and slag wastes of thermal power plants for environment and human health] Proceedings, 2nd Seminar, Ash and slag of power plants: removal, transport, processing, storage, Moscow, April 23-24, 2009.

2. Dik E. P.; Soboleva A.N.; Smirnova O.A. Klassy opasnosti zoloshlakov teplovykh elektrostantcii dlya okruzhaiushchei sredy [Environmental hazard classes of ash and slag of thermal power plants]. Teploenergetika; 2011, 6, 58-62 .

3. Burdina V.M.; Soboleva A.N.; Dik E.P.; Terekhova V.A. Effekt raznykh sposobov neitralizatsii na opredelenie ekotoksichnosti othodov TES [Effect of various neutralization techniques on determination of environmental toxicity of wastes of thermal power plants]. Ecological systems and devices; 2007, 10, 37-39.

4. Ėudiæ, V.; Kisiæ, D.; Stojiljkoviæ, D.; Jovoviæ, A. Ash From Thermal Power Plants
As Secondary Raw Material. Arh Hig Rada Toksikol; 2007, 58, 233-238

5. Belozerova T.I. Rekul'tivatsiia zolootvalov teplovykh elektrostantcii v usloviiakh Severa [Recovery of ash wastes of thermal power plants in North]. Cand. Thesis. Arkhangelsk, institute of Ecological Problems of the North, Ural Branch, Russian Academy of Sciences, 2006, 20.

6. Zhuravleva N.V. Obosnovanie, razrabotka $i$ razvitie metodov otscenki vliianiia dobychi $i$ pererabotki uglei kuznetckogo ugol'nogo basseina na ekologicheskoe sostoianie prirodnoi sredy [Substantiation and development of assessment techniques of influence of coal mining and processing at Kuznetsk coal basin on environment]. Doctoral thesis. Kemerovo, Institute of Coal Chemistry and Materials Science, Siberian Branch, Russian Academy of Sciences, 2017.

7. Terekhova V.A. Tekhnologii biotestirovaniia $v$ otsenke ekotoksichnosti othodov [Biotesting in assessment of environmental toxicity of wastes]. Ecology of Production, 2009, 1, 48-52. 
8. Vigand, A.K.; II'ina E.G.; Ivanova S.A. Khimicheskii analiz i biotestirovanie zoloshlakovykh otkhodov [Chemical analysis and biotesting of ash and slag wastes]. South-Siberian Scientific Bulletin; 2014, 3(7) , 97-100.

9. Tsiridis, V.; Samaras, P.; Kungolos, A.; Sakellaropoulos, G. P. Application of Leaching Tests for Toxicity Evaluation of Coal Fly Ash. Environmental Toxicology, 2006, 21, 409-416.

10. Kozhukhova N.I.; Lebedev M.S.; Vasilenko M.I.; Goncharova E.N. Ecology-toxicology study of low-calcium solid wastes from power plants. International Journal of Pharmacy and Technology; 2016, 8(3), 15349-15360.

11. Andreeva S.G. Gigienicheskaya otsenka zoloshlakovykh otkhodov, obrazuyu shchikhsya pri szhiganii uglei KanskoAchinskogo basseina [Hygienic assessment of ash and slag wastes after combustion of coals of Kansk-Achinsk basin]. Cnad. Thesis. Kemerovo State Medical Academy, Center of hygiene and epidemiology in Krasnoyarsk region, 2006, 20.

12. Korotkova T.G.; Ksandopulo S.Ju.; Bushumov S.A.; Burlaka S.D.; Say Yu.V. Quantitative Chemical Analysis of Slag Ash of Novocherkassk State District Power Plant. Orient. J. Chem., 2017, 33(1), 186-198.

13. Sindireva A.V. Vliyanie selena na himicheskii sostav pochvy i rastenii $v$ usloviiakh yuzhnoi lesostepi omskoi oblasti [Influence of selenium on chemical composition of soils and plants in Southern forest steppe in Omsk oblast]. Bulletin of Omsk State Agrarian University, 2011, 4(4), 17-22.

14. Taylor, S.R. Abundance of chemical elements in the continental crust; a new table. Geochimicu et Cosmochimicn Acta; 1964, 28, 1273 - 1285.

15. Dobrovol'ski, V.V. Osnovy biogeohimii [Foundations of biogeochemistry]: Guide book for students of higher schools. Akademiya, Moscow, 2003.

16. Greenwood, N.; Earnshaw, A. Chemistry of the Elements. Binom, Moscow, 2008, 670.

17. Gigienicheskie normativy GN 2.1.7.2041-06 Predel'no dopustimye koncentratsii (PDK) himicheskikh veshchestv $v$ pochve [Hygienic Norm 2.1.7.2041-06. Maximum Permissible Concentrations of Chemical Substances in Soil]

18. Gigienicheskie normativy GN 2.1.7.2042-06 Orientirovochno-dopustimye koncentratsii (ODK) khimicheskikh veshchestv $v$ pochve [Hygienic Norm 2.1.7.2042-06. Tentatively Permissible Concentrations of Chemical Substances in Soil]

19. Bushumov, S.A.; Korotkova, T.G.; Siukhov, H.R.; Burlaka, S.D.; Hachaturov, V.N. Granulometricheskii sostav zoly Novocherkasskoi GRES [Ash particle size distribution of Novocherkassk state district power plant]. Scientific journal, Kuban State Agrarian University; 2016, 124(10), 799-808. 